\title{
Journeying into the Complexities and Possibilities of Performative Pedagogical Practice, Research and Analysis
}

\author{
Gustave J. Weltsek
}

\begin{abstract}
In the United States, there is an obsession with high stakes testing, and performative pedagogues are challenged to prove that their work is valuable to increased scores. Educators who work through performative pedagogies are also expected to articulate the ways the work encourages and supports socio-cultural growth. In this article, the author calls into question trying to validate performative pedagogies based upon what they produce and or do and rather explores the complexities and possibilities of our work made manifest within observable discourses. Data was collected over the course of a year from a process drama with 20 pre-school students. Three students' stories provided the researcher the opportunity to articulate multiple ways in which student identities began to emerge. An articulation was made possible based upon how individual discourses were observable as students interpreted and acted upon the various social needs within both an institutionalized world of their school and the fictional world of a pioneer journey.
\end{abstract}

\section{Introduction}

In the United States, many public-school districts award schools grades A-F. These grades are based upon how well students perform on standardized tests. If a school receives an " $\mathrm{A}$ " it means students in that school have scored above average on standardized tests. If a school receives an "F" it means their students have failed to meet basic levels of standardized test proficiency. If a school receives an " $F$ " grade for several years that school is in danger of having their entire faculty replaced or worse being closed. Plainfield elementary school (pseudonym) had received an " $F$ " for the past 3 years and was in danger of being closed.

In this paper, I reflect upon my one year involvement in one preschool class at Plainfield elementary school, my thoughts around performative pedagogy (Even 2016, 2007; Weltsek et al. 2007; Medina et al. 2006; Fels 2000), and the use of process drama (O'Neill 1982). My involvement was part of a grant 
designed to support creative projects that increased standardized tests scores in low achieving and or "failing" elementary schools. I share the experiences of three preschool aged Plainfield students (4-5 years old) involved in the drama project: Winton, Felicia and Cody. This is done as a way to begin to unpack the "complexities and possibilities" (Gaztambide-Fernandez 2017: 214) found in the use of performative pedagogy with youth. My inquiry centers around the challenges connected with articulating what happens as students engage in performative pedagogy. The research question becomes: is it possible to create an articulation of what students go through within a process drama that honors the emergent quality of a performative pedagogy?

My inspiration for this comes from the field of critical literacy, specifically Leander \& Boldt (2012). Leander \& Boldt challenge researchers " $\mathrm{t}] \mathrm{o}$ run counter to the expectation that we should be seeking to represent what actually happened or to locate causality in the subject of the event" (ibid. 25). In other words, the challenge is to resist the temptation to interpret what we observe happening during a drama and rather focus on the ways in which what does occur emerges in the moment.

To explore these ideas, I first provide background into the project. Next, I briefly describe the theory and research methods which guided my thinking, data gathering and analysis. This is followed with the stories of Winton, Felicia and Cody. My hope is to contribute to the multiple ways in which scholarship and research explore, reflect and document performative pedagogy.

\section{Project Background}

As part of the Plainfield grant I worked closely with host teacher Liali (pseudonym) to create a year-long process drama around a common theme. A process drama, made popular by Cecily O'Neill (1982), contrasts with a theatre production, or mounting of a play for an audience. The intent of a process drama is to situate the learning as inherent in the process of participation in the creation of a fictional world. In a process drama students and teacher alike take on fictional roles around a common theme to improvise a fictional or imaginary world. There is no expectation in a process drama that a production for an audience will take place. The only expectation is that the social interactions that emerge within the fictional world improvisations will engage the participants in problem solving and meaning making. It was hoped that, along with other efforts throughout the school, infusing a process drama into the curriculum would help improve standardized tests scores and raise the school's standing above an "F" and save it from being closed. Not only was Plainfield a failing school it was also a Title 1 school. When a school in the US is designated as Title 1 it means that the Social Economic Status (SES) of the school has a high percentage of children from low-income families. When a school is designated Title 1 the United States federal government provides financial assistance to local educational agencies and schools to help ensure that all children meet challenging state academic standards. 
Indeed, many studies have supported the idea that the use of drama helps improve academic achievement such as: Walker et al.'s (2011) study on literacy achievement, Smithrim \& Upitis' (2005) article on mathematics achievement, and Catterall's work (2009) on how the Arts positively affect academic achievement and social growth with underserved students. Similarly, many studies have articulated the ways in which drama and the Arts affect how youth understand themselves and the world (Gallagher 2007; Edmiston 2008; Medina 2004; Allen 1979). Both Liali and my hopes rested somewhere between the two. We intended to use a performative pedagogical approach where "[i]nstead of being passive recipients of knowledge doled out by the teacher in pre-processed doses, learners become agents of their own learning (...)" (Even \& Schewe 2016: 176). Based upon our past experiences with performative pedagogies, our use of drama, and our research into its effectiveness we set out to design a process drama that allowed the students to play with real-life issues. It was our stance that through their engagement with the socio-cultural experiences which emerged throughout the process drama, students would become agents of their own learning and academic and personal growth would occur. And we certainly hoped for increased standardized tests scores.

However, even as we created our lessons, studies surfaced that challenged claims that the Arts actually do help academic achievement. Foster \& Jenkins (2017) use large United States educational data sets for example, to compare standardized test scores of students who took music courses and those who did not. They break these scores down by demographics and conclude that students with high SES, mostly white and native speakers with parents with a high level of education score better than their lower SES, poor white, marginalized and non-native speaker peers. In short, Foster \& Jenkins claim that it is a student's access to a wide range of intellectual and academic experiences supported through their family's high level of education and wealth that result in higher test scores and not involvement in the Arts. They also claim their large data set analyses "weaken efforts to bolster support for arts education by linking it to benefits outside of the arts, including test scores" (ibid. 437). Liali and I panicked. If Jenkins \& Foster were correct we were in trouble. Although we might be able to provide our students with an experience that enriched their sense of self and notions of community our students were Title I students, low SES and according to Foster and Jenkins there would be no positive academic growth and more our attention to raised test scores might very well jeopardize any socio-cultural growth.

In rebuttal to Foster and Jenkins, Gaztambide-Fernandez explains: "This ability to demonstrate what the arts do-whether it is to improve achievement or to make us better human beings-has become the holy grail of arts advocacy." (2013: 213). Gaztambide-Fernandez's statement challenged the core of our beliefs as performative pedagogues. After all we were awarded a grant based upon the premise that the inclusion of drama into this preschool class would do "something" in particular it would raise standardized test scores or hopefully enrich the youth's sense of self. The point of the process drama for us as 
educators and researchers now became obscured, blurred and illusive. If we weren't trying to observe for effective change either in socio-cultural or academic growth what were we looking for or at?

Gaztambide-Fernandez further speculated that,

Indeed, in a literature that is primarily about advocacy, even claims about the power of the arts to inspire, to liberate, or to transform tend to obscure both the complexities and the possibilities that lurk within experiences with the arts in education (ibid. 215).

Liali and I struggled over how to proceed. Gaztambide-Fernandez challenged us as performative pedagogues and researchers to imagine observing and commenting upon seemingly ungraspable concepts of "complexities and possibilities" that may emerge as students engage in the creative "doing" of drama. How would we create and research a process drama that used the real-life issues we knew to be valuable, meaningful and relevant to the students, keep an eye on how these engagements within the drama were affecting student achievement on standardized test scores yet resist the temptation as scholars to impose socio-cultural meaning onto the moments as they happened?

\section{A Pioneer Journey}

I had just come from an experience with my daughter's elementary school, a grade "A" school in a wealthy part of town, where they "celebrated" of the United States Westward Expansion. In 1803 then president Thomas Jefferson bought the Louisiana territory from the French for $\$ 15$ million dollars. The territory extended from the Mississippi river to the Rocky Mountains and from Canada to New Orleans. This basically doubled the size of the US. In order to settle this land, nearly 7 million people migrated westward. This school used the book by US author Laura Ingles Wilder, "Little House on the Prairie" as a launching point for the students' immersion into a drama enactment called "Pioneer Days". During "Pioneer Days" the students dressed in romanticized pioneer costumes, sang uplifting songs about the adventure of travel, danced joyful folkloric square dances and ate delicious food meant to replicate foods the pioneers would have eaten.

In "Frontiers of Women's Writing: Women's Narratives and the Rhetoric of Westward Expansion" (1996), Georgi-Finlay paints a decidedly different picture of the Westward Expansion. Georgi-Finlay examines diaries from women who made the journey. Through her reading she finds "in their texts a more detached and perhaps critical narrative of westward expansion that could bring into focus the problematic legacy of violence and disenfranchisement that accompanied the Euro-American move west." (ibid. x). Georgi-Finlay presents the murders and land theft of the peoples of first nations, the deaths of thousands of pioneers, and the abuse by wealthy investors who took advantage of the poor in essence forcing them to make the journey. Missing from the celebratory "Pioneer's Day" 
of my daughter's school was any opportunity for the students to engage with the socio-cultural complexities that accompanied the US Westward Expansion.

Liali and I felt that the idea of a Pioneer Journey process drama would suit not only the students but our own needs very well. After all, as scholars and pedagogues we were taking our own pioneer journey into an emergent space looking for complexities and possibilities. For the students, we would create a process drama that allowed them to engage in thinking about issues of power and justice connected with the westward expansion. Like Gallagher we believed that by creating these complex socio-culturally loaded drama's "[s]tudents are always living by and challenging theories..." (2001: 130). We set out to create a process drama where spaces emerged for students to challenge traditionally held romanticized theories and perspectives of the US expansion west.

We hoped that our drama world would present the students with a space to play with multiple ways to respond to a wide range of social issues. We imagined this would occur through their consideration in role of the real life issues, ethical struggles, moral challenges and the honest pain the pioneers confronted as they made the journey westward. Similar to Medina who feels that "[e]mbedded in these activities were clear political and power discourses that emerged as the students named and unpacked the nature of being a new person in an unknown community" (2004: 187), we set out to create rich socio-cultural interactions that allowed us to articulate the many ways students performed observable discourses as they engaged with an emergent sense of self as they negotiated moments of power.

\section{The Fictional World}

On the first day of the process drama Liali and I created and shared the following story as a pretext to introduce the students to the fictional world of the Process Drama.

Greenville Indiana was a small farming town, population 100. Of those 100 people, there were 12 families. The people of the town were close and everyone got along and helped one another. Not only were they good farmers they also had a knack for carpentry and building wagons and carts. Unfortunately, there was a horrible drought and no crops would grow. The people were broke and did not know what to do.

Our first strategy was to ask the students to imagine what kind of people would live in Greenville. How old might they be, what kind of jobs would they have and what types of games might they play? After a few minutes we had compiled a large list of types of people and activities in which they might engage. The students were told that we were going to pretend to be these people. We went around in a circle and the students made up names and small stories about who they were in Greenville and what their jobs were and what kinds of things they liked to do. (See Table 1 for a sample of responses) 
Table 1: Student Character Creation

\begin{tabular}{|c|c|c|}
\hline $\begin{array}{l}\text { Student Name } \\
\text { (Pseudonym) }\end{array}$ & $\begin{array}{l}\text { Character } \\
\text { Name }\end{array}$ & What they did in the town \\
\hline Jacob & Sam & $\begin{array}{l}\text { "I'm a farmer, on a farm and plant things with } \\
\text { cows" }\end{array}$ \\
\hline Shantel & Missy & $\begin{array}{l}\text { "Baby Doctor. I wanna be that person who does } \\
\text { the babies" }\end{array}$ \\
\hline Sophia & Becca & "I'm the mayor. Yup" \\
\hline Calib & Rex & $\begin{array}{l}\text { "I'm an inventor, I make things people need to help } \\
\text { us." }\end{array}$ \\
\hline
\end{tabular}

At this point the school's principal entered the room in role as Mr. Banks, a rich person from the big city to the East. Mr. Banks offered the Greenville town's folk money to move to a new home "Where the land is green and healthy crops can be grown." Mr. Banks also offered them extra money for the trip if they built wagons and redesigned them during their journey based upon what they found the wagons needed. A contract was produced and ritualistically one by one the students signed it and our journey began. (See Table 2 for a sampling of the strategies used throughout the process)

\section{Research Methodology}

I position this work as a mixed methods (Tashakori et al. 2003) case study (Stake 2000) with the intention that it uses both quantitative and qualitative data and will broaden and deepen understanding of an experience (Medina 2004). I used aspects of Grounded Theory (Strauss \& Corbin 1990) for the creation of emergent categories through open coding as a way to begin to imagine possible emergent moments. As a qualitative exploratory design (Marshall \& Rossman 2011) data was gathered from all planning meetings between myself and the host teacher, lesson and unit plans and field notes, as well as student-produced artifacts such as drawings and sculptures. I also gathered video and audio footage of all drama work. The terms of the grant required that quantitative data was gathered as a means to show student growth on standardized tests. Data on academic achievement was gathered through their performance on the school's mandated Individual Growth \& Development Indicators (IDGI). The IDGI tests were Picture Naming (oral language), Rhyming (phonological awareness), Alliteration (phonological awareness), Sound Identification (alphabet knowledge), Which One Doesn't Belong? (comprehension). In a quasi-experimental fashion data was also collected from a control group. The control group was selected due to similar demographics and Title 1 rating. Test scores from both the populations were compared. Chi Square was used to compare success rates: grades of A, B, or C were coded as successful, and grades of D and F were coded as unsuccessful. The Grade of " $\mathrm{A}$ " represents the highest achievable grade and "F" represents 
Table 2: A sampling of the strategies

$\begin{array}{ll}\begin{array}{l}\text { Strategy } \\ \text { Name } \\ \text { There's a } \\ \text { problem }\end{array} & \begin{array}{l}\text { Description } \\ \text { Ine "pioneers" that "All our } \\ \text { crops have died. What are we } \\ \text { going to do?" Students in role } \\ \text { respond with possible solutions }\end{array} \\ & \\ \text { Choose a } & \begin{array}{l}\text { A group of antique pictures } \\ \text { placed on a table. Each } \\ \text { Pen Pal }\end{array} \\ & \begin{array}{l}\text { student was invited to select a } \\ \text { picture to be a friend who } \\ \text { already made the journey }\end{array} \\ & \begin{array}{l}\text { West. The youths were then } \\ \text { given a template and asked to } \\ \text { write or draw their friends } \\ \text { letters. }\end{array}\end{array}$

Tableau Students were invited to create living statues that represented how they felt about going on this journey and leaving their friends and homes behind.

\begin{tabular}{|c|c|}
\hline $\begin{array}{l}\text { Town } \\
\text { Meeting(s) }\end{array}$ & $\begin{array}{l}\text { These were recurring events } \\
\text { and included not only the } \\
\text { "Pioneers" but the people(s) } \\
\text { they met along the way. Some } \\
\text { of these meetings included } \\
\text { things like a trial and a } \\
\text { discussion with the people who } \\
\text { already lived in a piece of land } \\
\text { the pioneers wanted to settle. }\end{array}$ \\
\hline
\end{tabular}

Wagon The students in role as expert Design wagon builders designed and redesigned wagons as they travelled across the west.
Intention

This was one of the first strategies and was designed to bring the students into the "Drama" and the role play of the fictional world. It establishes the teacher as part of the collective and presents the students with the opportunity to make decisions.

This piece aligns the socio-cultural nature of the drama with the curriculum. We are further immersing the students in the fictional world and providing them with a way to question the journey and do some "research" as they gather and share information from their friends' responses. (Liali and I both answered the students' letters in role as the pen pal). We were also aware that we were working with writing literacy asking students to "write" letters. During this writing Liali and I would assist students in connecting English letters to some of the drawings as well as helping those who were beginning to play with formal writing.

To engage the students in the embodied experience of meaning making. To struggle with issues of loss and newness and going into an unknown situation. We shared "Just like your first day of preschool”.

To further invest in the students' sense of themselves as owning this event. These meetings had them argue, disagree, find common ground and sometimes not resolve issues. Over the course of the year these meetings also became a space for the students to construct their own understanding of the need for order, taking turns and mutual respect.

Here again we blended curriculum with socio-cultural work. Math and measuring, shapes and editing came into play and also collaboration, discussion, negotiation, logic and decision making. 
failure. Also, an independent sample t-test was used to compare the students cumulative grade point averages (GPA). A GPA is a cumulative average total of a student's achievement gathered across an entire semester. All data was stored in a locked file cabinet and will be destroyed five years after the completion of the study. Pseudonyms are used throughout. Human subject approval was applied for and awarded by the primary investigator's university.

\section{Theoretical Influences}

I situate my work as a critical performative pedagogy,

where classrooms are perceived as spaces where students and teachers perform and imagine multiple social realities addressing political issues, moving beyond superficial understandings of 'difference', 'the other,' or assumed 'naïve' notions of empowerment, and instead explore the embedded multiplicity of discourses (Weltsek et al. 2007: 78).

In this view, classrooms become spaces where "what is real" emerges as both students and teachers alike imagine the possibilities of what may be. The use of process drama then becomes a way to open up spaces for a critical performative pedagogy where individual and collective imaginative realities may emerge within the creation of character choices and actions within the needs of the fictional world.

My work rests in the perspective that youth and educators embrace the idea that reality, and by way of connection, power and identity are no more than "performances". More, I believe that these performances are constructed through a critical reflection upon past experiences, present needs and future expectations. Garoian felt for example; that this idea of the performed self or performance "represents an expanded, heterogeneous field of cultural work within which the body performs various aspects of production, socially and historically constructed behaviors that are learned and reproduced." (1999: 8) This is to say, that not only are our identities constructed roles which we play requisite upon determined, cultural, political social etc. needs, but that more these roles, these performances of self, are learned. What becomes important for this work is that what is learned may be unlearned. For the youths and faculty in this study then, how they "performed" power across the institutionally constructed roles within "This is learning", as in this is how a student performs and this is how a teacher performs may be disrupted, critiqued and reimagined.

Also, influencing my perspective on the use of a process drama within a critical performative pedagogy is Gallagher's (2007: 107) thought that "the individual with the whole," as participants "often grasp the actual through the fictional when their world becomes mapped into the 'world' they are creating". Gallagher's ideas led me to think that the students' actual lived experiences outside of the drama emerge, and become relevant as they are challenged through various drama scenarios. For example, a student may have a lived experience that reinforces the idea of male gender dominance yet in a drama 
may find themselves being told what to do by a female. Edmiston points out: "When people play together as they make meaning they can co-author possible selves and over time possible ethical identities" (2008: 22). Drama then becomes a way for individuals to consider their own sense of self in relationship to others with the idea that some "thing" or some "one" new will emerge as a result of the interaction.

I am also influenced by Gee's work in critical discourse analysis. Gee (1998) describes discourses: "ways of being in the world; they are forms of life which integrate words, acts, values, beliefs, attitudes and social identities as well as gestures, glances, body positions and clothes" (ibid. 7). Using Gee's notion of discourse process drama then becomes a fantastic way to allow those discourses to emerge and become observable and in this way, be designated as "observable discourses". The use of drama provides students with the opportunity to use vocal, physical, and visual representations, and traditional writing to perform discourses. As a researcher intent on the complexities and possibilities which emerge within the drama, focusing on observable student discourses provides a lens for articulation.

\section{Sharing Their Stories}

\subsection{Winton}

Image 1 shows the "Sharing Circle". The Sharing Circle was a daily event where the teacher would lead the group in sharing anecdotes from the students' lives. It was intended to provide "a space for the students to use their voices and practice using their words in an authentic and structured way" (Teacher interview). In the depicted moment the students are reflecting back upon the previous day's process drama as a way to enter the story where we left off. In the audio, in a barely perceptible voice, she whispers that "We've gone a way in the Wagon.... and we've done some things...". In the visual you can see Winton looking down at the ground, fidgeting and looking at the teacher to see if what she is doing is ok.

In Image 2, Winton is in role now as the leader of an indigenous people. In role she is being confronted by the teacher in role as a pioneer, who is seeking to live in the indigenous people's town. In the audio Winton loudly proclaims "No you can't live here! No you be quiet! I am the boss of the all these people! You can't stay! No!" In the visual you can see her body language. She is sitting up straight, hands on the table in a very aggressive manner pushing herself chest first forward. She makes direct, stern and constant eye contact with the teacher in role as one of the pioneers.

Seconds later in Image 3, Winton is back in the "Sharing Circle" where she adopts the same behavior as in the earlier sharing circle. Once again Winton performs in response to her perception of the needs/protocol of the space by being quiet, waiting her turn, looking to the teacher to know how she is doing and not dominating the conversation. 


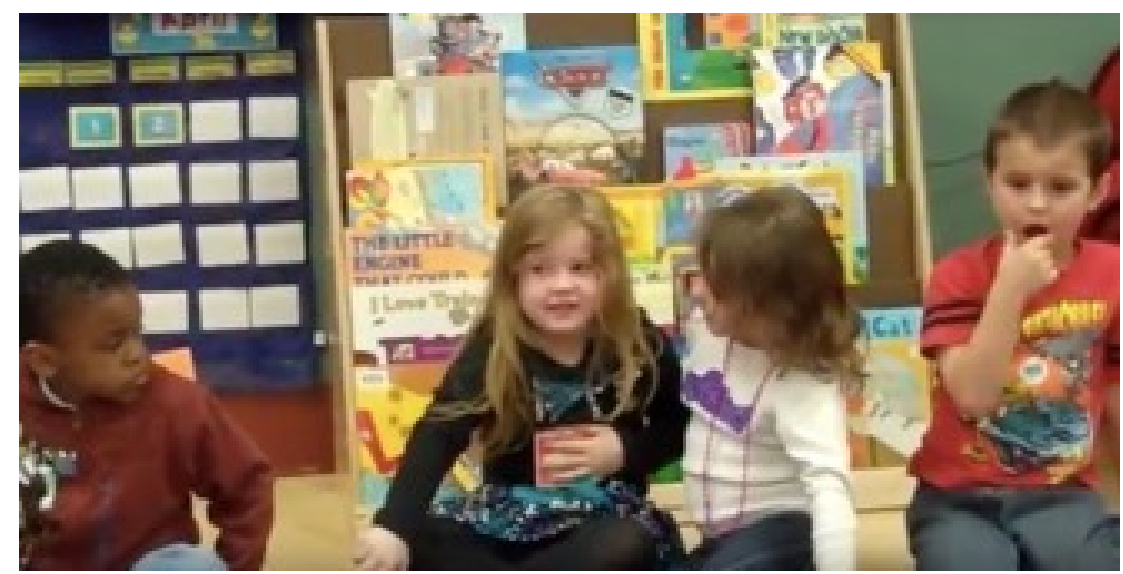

Figure 1: Winton quietly sitting in circle

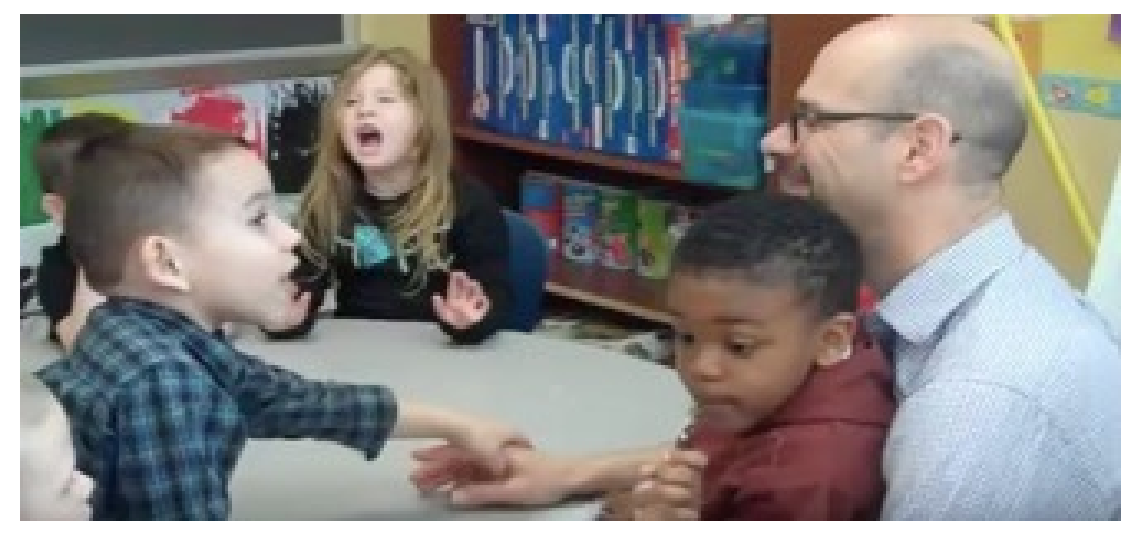

Figure 2: Winton as Town Elder

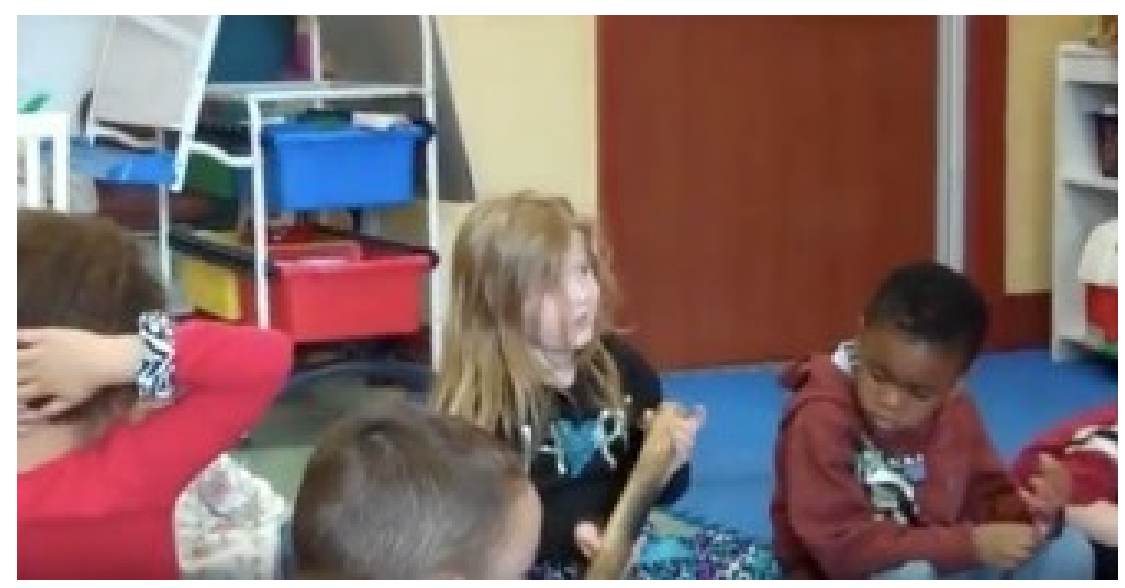

Figure 3: Winton quietly sitting in the circle 
In each moment Winton engages in different types of performance of an observable discourse. Both these performances emerge as Winton plays out the needs of the moment. In the sharing circle Winton's identity emerges as she performs her role as student. In this role the needs ask her to acknowledge the protocol of the "system" the teacher has created to allow a productive and positive community sharing. In the drama Winton's performance emerges within the needs of the fictional world of her role as "leader". As leader she must speak for the community. As Medina \& Perry (2014) explain:

The performance itself does not reflect reality any more than the media does, but it does reflect relations between media and student, between good and passive behavior, between safe and violent spaces (ibid. 129)

In each instance Winton plays with performances of her "Self" in complex and meaningful ways based upon her perception of the needs of the moment. She experiments with both spoken and embodied language as she plays with ways to interact. As she does experiment she invents identity situated within her notion of self as a literate individual who knows how to use language to defend herself and her own interests and beliefs.

\subsection{Felicia}

Felicia was a first-generation newcomer from Mexico. Felicia's parents spoke little to no English. I was told by Liali that "Felicia's use of English was incredibly limited and was compounded by her parents' lack of English" and the fact that "Felicia was incredibly shy". Similar to Winton, Felicia's performance of self may be seen to emerge differently based upon the needs of the particular moment.

Over my one year work with the group there were many times when Felicia was "caught" speaking. I say caught because she did not use language, either Spanish or English in the presence of an adult. It was only when Felicia was in small groups or working with a partner that she would use language. As soon as either Liali or myself entered the group Felicia stopped talking. In these moments the needs that guided Felicia prevented her from engaging with adults and resulted in a sense of self that emerged in a performance of silence and reserve. It is difficult to imagine what or how Felicia perceived the needs of the moment. Nieto though offers a possible clue; speaking about English language education she wrote; "Losing's one's culture and language is an unnecessarily high price to pay for academic success and social acceptance" (1996: 4). Perhaps in these moments Felicia saw that she needed to preserve her sense of self in the face of Liali and my insistence that she speak in English.

The needs that guided her during the drama however seemed to be based on interaction and a performance of self that freely communicated. One moment in particular resonates with the place that performative pedagogy may play in the ways in which youth voice and identity emerge. In this moment, as part of their in role adventure as pioneers, the students were invited to design/draw their ideal new home. The pioneers had been traveling now for over three 
months, had overcome all sorts of obstacles both physical and emotional and within days they would reach the new land and would need homes. After the students/pioneers designed the homes they were given flip top cameras, instructed on their use and invited to interview a partner about the new home design. The below excerpts from Felicia's response to being interviewed and her interview of her partner reinforce some insights to the ways in which Felicia was reading the needs of the moment.

Felicia: So, tell me what did you draw?

Malici: It's a um it's a ... my house.

Felicia: Yes, ok... and why did you draw it like that? You like this colors?

Doggies too. There.

Malici: Yes I have two.

Felicia: What kinds?

Malici: Big one, brown and a black..its little.

Felicia: I don't like doggies. I like bunnies.

Malici: I have a fish.

The voice recording goes on with the two engaged in an intense conversation about their real homes never returning to the interview topic of the design. What is striking is that Felicia is not only speaking but using English in ways that neither her teacher nor myself had ever witnessed. The needs of the moment to share an idea of her dream home motivated her to freely use English. When the roles were reversed and Felicia was interviewed by Malici an even more interesting quality emerged. That quality was that Felicia exerted power over Malici in the form of directing the conversation.

Malici: What di you draw?

Felicia: It's my dream house.

Malici: Do you have dogs.

Felicia: No Malici I told you I don't like dogs and this is my dream house. So no dogs.

Malici: Oh.

Felicia: Now if it was bunnies I'd have lots. But I didn't put them. I drew it blue with a smoke out the top. I like it.

Malici: Uh hu.

Felicia: You wann know what else? 
Malici: Uh hu.

Felicia: I have grass and a garden, wit rose and flowers.

Similar to the moment when Felicia was being interviewed, this exchange shows an active and engaged Felicia who is comfortable using English. Unique to this exchange is the way in which Felicia is seen to take control of the conversation. At times Felicia lets Malici know that they have gotten off track "No Malici I told you I don't like dogs and this is my dream house. So no dogs." Here Felicia is moved to remind Malici of the need of the moment to stick to the fiction and not stray into a tangential conversation. What is evident however, is that once again the student's sense of self has emerged based upon how she perceives the needs which define the moment.

\subsection{Cody}

Cody was a "good kid". It was his way to perform the role of helper in the class always caring for the other children as best he could. He followed Liali's instructions and rarely "misbehaved". When he did "mess up" it was a very mild mistake like talking when he should not or accidently hurting another child's feelings. On these occasions he was highly apologetic, eager to make reformations and very tough on himself. For Cody the needs of the classroom were very clear: behave, follow the teacher's rules and be nice to others. His performance of self in the classroom emerged in direct correlation. Within the fictional world of the drama Cody followed the needs of each new situation and multiple notions of a self emerged. For example, in one moment the group was challenged with the theft of water. In the fiction the pioneers had been in the desert for days, they had not been able to find any fresh water and the reserves were running low. As a group they had decided to ration the water with everyone "promising to not take the water". One morning however the water was gone and it was clear that someone had stolen it as many bottles were also missing. Out of role, although no one had been accused or caught, the students decided that they needed a trial. I brought it to the group's attention that we did not have anyone to put on trial and we needed volunteers to pretend to be the ones who stole the water. There was silence. It appeared that none of the students wanted to be guilty of breaking a promise.

The needs of the fictional world asked that the students embraced the role of breaking the rules of being bad. Cody stepped up. The following is the exchange between him and myself about him taking the role.

Me: Why do you want to do this role?Cody: I like playing the bad guy!Me: Really why's that? Cody: Cause I can be bad! I can't be bad.Me: What?Cody: Yeah! I'm not allowed to be bad but I want to.Me: Do you mean you want to be bad in school?Cody: (Shaking his head no)Me: No?Cody: (Again shaking his head) yeah no. I like being good. But I want to be bad! I want to try it. In this moment, Cody was able to communicate his understanding of the complexity and possibilities within the drama. He knew that in the drama the 
needs shifted and rules changed. How he was going to perform would emerge based upon these different needs. Edmiston explains: "Children choose to play, know that they're playing, and understand that whatever events they pretend are happening are not actually occurring" (2008: 54). It would seem as if Cody was able to articulate Edmiston's thoughts. Cody somehow felt safe and knew that through the needs of the fictional world the rules had changed and it was ok to "try" different roles - to be bad.

\section{Complications}

In a climate where results and conclusions are demanded taking the risk to dwell in the unknown in the complexities and possibilities is frightening. In the US we are obsessed with assessment, evaluation, product and the proof that what we do makes a difference in the intellectual, social emotional and even the spiritual lives of the youth with whom we work. Educational theorist Freire explains that "[i]n the banking concept of education, knowledge is a gift bestowed by those who consider themselves knowledgeable upon those whom they consider to know nothing." (1998: 53) It occurs to me that prior to taking this pioneer journey my sense of what I was doing as educator and researcher were indelibly tied to my own sense of privilege and power within the exchange with the students. The challenge to stay within the complexities and possibilities felt overwhelming. Even as I created a process drama intended to problematize issues of power, equity and justice within the Westward Expansion my intellectual predilection was to ignore the affect my own politics and belief systems had upon the interpretation of the students' experience. More what of the obligation to the granting organization looking for quantifiable proof that a performative pedagogical approach through Process Drama has value within the US educational system obsessed with high stakes testing?

Using results from a pre and post-test called the Individual Growth \& Development Indicators (IDGI) there was a 135\% increase in Vocabulary (oral language), a 271\% increase in Alliteration (phonological awareness) and a $466 \%$ in Rhyming (phonological awareness) (See Figures 1-3). According to Foster and Jenkins I should not have seen these results and as far as Gaztambide-Fernandez I shouldn't even have bothered. Also, how do I reconcile the nagging desire to make a case for the value of a performative pedagogical approach to learning when in each case while in role in the drama Winton, Felicia and Cody each showed a very powerful sense of personal agency and engagement that they did not exhibit when engaged in the needs of the real life classroom?

Clearly, standard assessments, while providing insight into the ways students are able to assimilate dominant paradigms, fail to address the more complex socio-cultural qualitative experiences. Similarly, as compelling as the anecdotal data from the students' stories may be as a means to support the use of drama as a way to enrich the lives of students I cannot in good conscience attempt to make a direct correlation. I am unable to do this for no other reason than my 


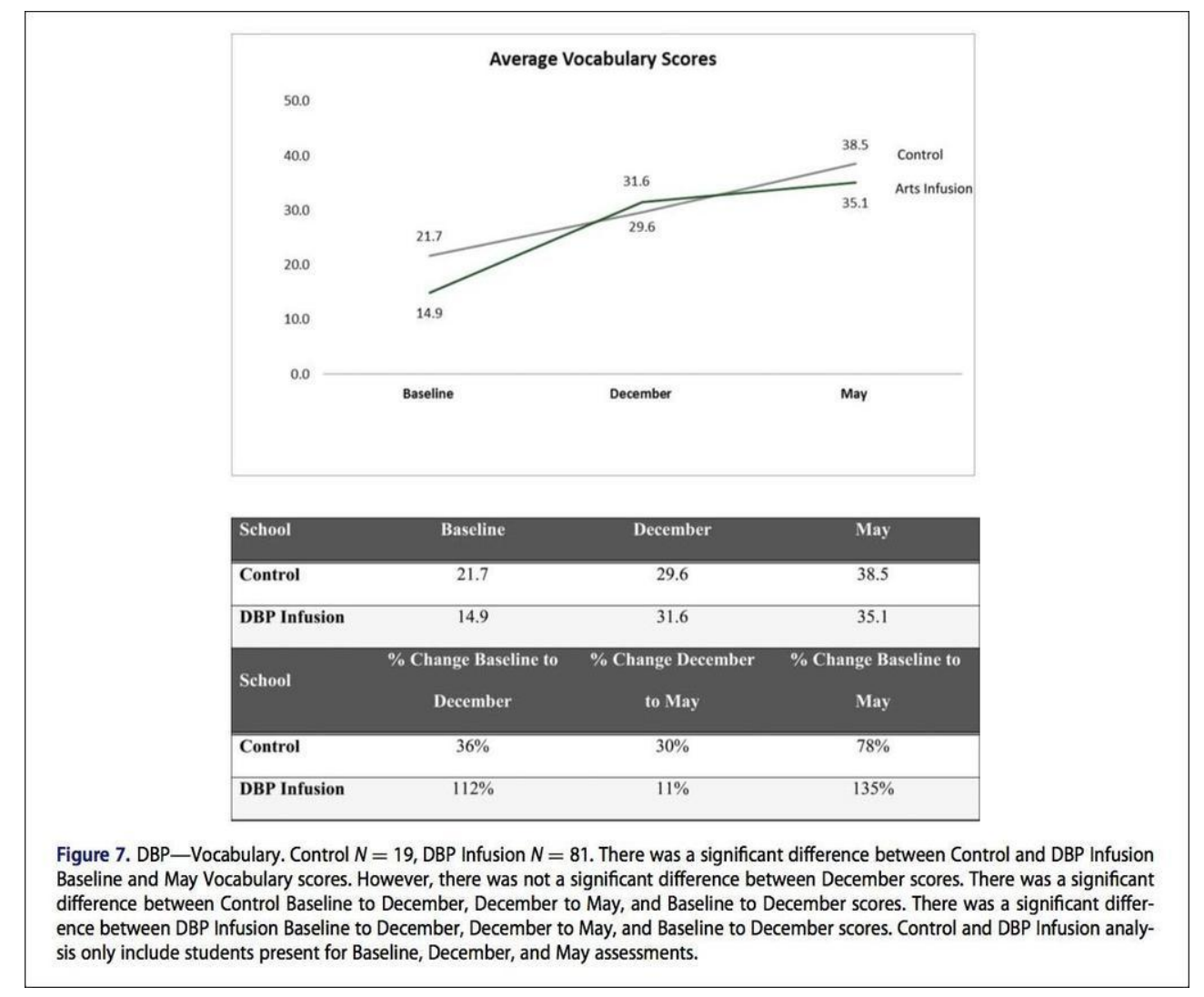

Figure 4: Average Vocabulary

inability to state with any sense of finality what "to enrich" may mean outside of my own ethics, ideologies and morals.

\section{Conclusions}

Perhaps a promising approach for performative pedagogues and researchers may be to find value in a description of the moment of doing and leave the interpretation up to the reader. As Carter explained:

Despite our fondest wishes, we cannot escape the problems of interpretation and meaning, either by ignoring them or by claiming to overcome them. We can only deal with them self-consciously and directly, using whatever tools we can to track their influence on our thinking and resisting as strenuously as possible the impulse by ourselves and others to elevate a particular interpretation to the status of doctrine. (1993: 10)

In each student's story, there were moments where the emergent self could be observed, both inside the fictional world of the drama and in the real-life drama of the classroom. In both spaces the students showed agency as they made 


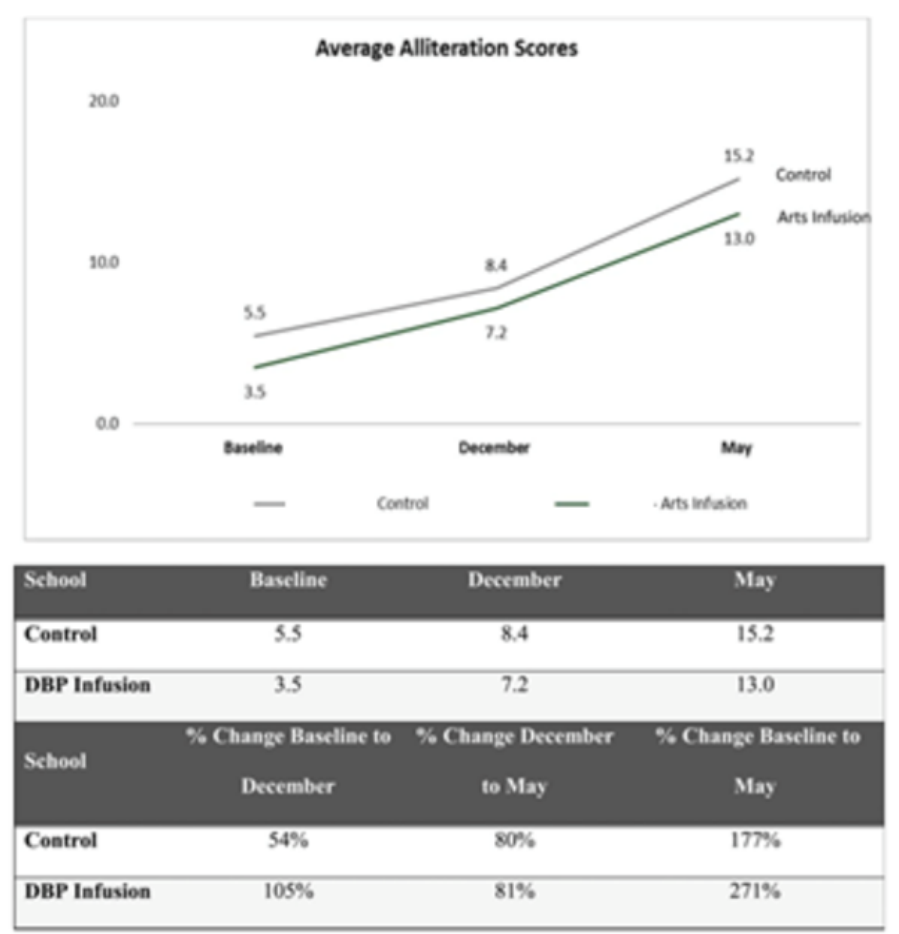

Figure 8. DBP-Alliteration. Control $N=17, \mathrm{DBP}$ Infusion $N=6$. There were no significant differences between Control and DBP Infusion Baseline, December, and May Alliteration scores. There was a significant difference between Control Baseline to December, Decem. ber to May, and Baseline to December scores. There was a significant difference between DBP Infusion, December to May and Baseline to December scores, but not Baseline to December. Control and DBP Infusion analysis only include students present for Baseline, December, and May assessments.

Figure 5: Average Alliteration

choices on how to perform within the perceived needs of any one particular social interaction. They used language and explored who they were, subverted and or reinforced institutionalized learning structures which inform how a person should perform. Within the drama moments there was a sense that a critical performative pedagogy took place where each individual used language to forward an emergent discourse of who and what they were and how the moment would be played out. Both spaces held meaning and informed one another. Trying to validate the truth or rightness of one experience over the other would seem a fruitless venture. Rather this study has provided me with another perhaps more abundant perspective, namely that the value of a performative pedagogy lay not in the outcomes or affects but rather in the ability to provide insight into the ways in which our sense of self alters based upon our perceived social needs within any one experience. Here is a way to dwell in the complexities and possibilities not only of drama but of life itself. 


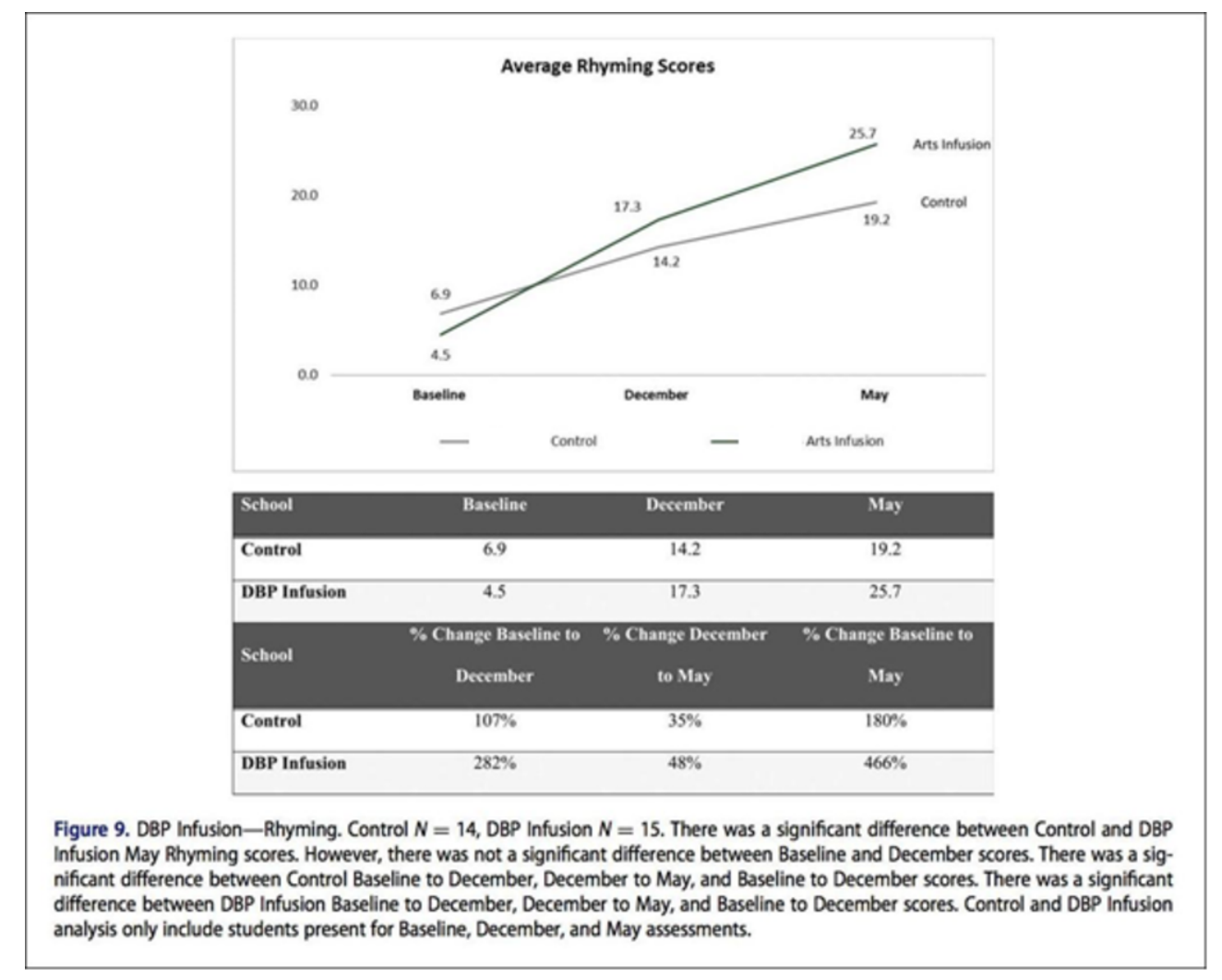

Figure 6: Average Rhyming

\section{Bibliography}

Allen, John (1979): Drama in Schools: Its Theory and Practice. London: Heinemann

Carter, Kathy (1993): The place of Story in the Study of Teaching and Teacher Education. In: Educational Researcher 22, 10

Catterall, James (2009): Doing Well and Doing Good by Doing Art: The Effects of Education in the Visual and Performing Arts on the Achievements and Values of Young Adults. Los Angeles/London: Imagination Group/I- Group Books

Edmiston, Brian (2008): Forming Ethical Identities in Early Childhood Play. London: Routledge

Even, Susanne \& Schewe, Manfred (2016): Performatives Lehren Lernen Forschen: Performative Teaching Learning Research. Berlin: Schibri

Even, Susanne (in print): Nothing moves if you don't let go. Performative teacher training. In: Fleiner, Micha \& Mentz, Olivier (eds.): The Arts in Language teaching. International Perspectives:

Performative-Aesthetic-Transversal. Münster: Lit Verlag 
Fels, Lynne (2000): Intercultural Recognitions Through Performative Inquiry. In: Gerd Bräuer (ed.): Body and Language. Intercultural Learning Through Drama. Westport, CT and London: Ablex, 19-36

Foster, Michael \& Jenkins, Marcus (2017): Does Participation in Music and Performing Arts Influence Child Development? In: American Educational Research Journal 54/3, 399-443

Freire, Paulo (1998) pedagogy of the oppressed. New York, NY: The Continuum Publishing Company

Gallagher, Kathleen (2007): The Theatre of Urban, Youth and Schooling in Dangerous Times. Toronto: University of Toronto Press

Garoian, Charles R. (1999): Performing Pedagogy: Toward an Art of Politics. Albany, New York; State University Press of New York

Gaztambide-Fernández, Rubén (2013): Why the Arts Don't Do Anything: Toward a New Vision for Cultural Production in Education. Harvard Educational Review: April 2013, Vol. 83, No. 1, 211-237

Gee, James (1989): Literacy, discourse and linguistic: Introduction. In: Journal of Education 171/1, 5-17

Georgi-Findlay, Brigitte (1996): The frontiers of women's writing: women's narratives and the rhetoric of westward expansion. Tucson: University of Arizona Press

Leander, Kevin \& Boldt, Gail (2012) Rereading "A Pedagogy of Multiliteracies": Bodies, Texts, and Emergence. In: Journal of Literacy Research 45/1, 22-46

Marshall, Catherine \& Rossman, Gretchen (2011): Primary Data Collection Methods Designing Qualitative Research. Los Angeles, CA: SAGE

Medina, Carmen \& Campano, Gerald (2006): Performing identities through drama and teatro practices in multilingual classrooms. In: Language Arts 83/4, 332-341

Medina, Carmen (2004): The construction of drama worlds as literary interpretation of Latina feminist literature. In: Research in Drama Education 9/2: $145-160$

Nieto, Sonia (1996) Affirming Diversity: The Sociopolitical Context of Multicultural Education. White Plains, NY: Longman

O’Neill, Cecily \& Lambert, Alan (1982): Drama Structures: A Practical Handbook for Teachers. London: Hutchinson

Smithrim, Katharine \& Upitis, Rena (2005). Learning through the arts: Lessons of engagement. In: Canadian Journal of Education/Revue canadienne de l'education, 109-127

Stake, Robert (2000): Case study. In: Denzin, Norman \& Lincoln, Yvonna (eds.): Handbook of qualitative research (2nd ed.). Thousand Oaks: Sage Publications, 435-454

Strauss, Anselm \& Corbin, Juliet (1990): Basics of qualitative research: Grounded theory procedures and techniques. Newbury Park, Thousand Oaks: Sage Publications 
Tashakkori, Abbas \& Teddlie, Charles (2003): Handbook of Mixed Methods in Social \& Behavioral Research. Thousand Oaks: Sage Publications

Walker, Elaine; Tabone, Carmine \& Weltsek, Gustave (2011): When Achievement Data Meet Drama and Arts Integration. In: Language Arts 88/5, 365-372

Weltsek, Gustave \& Medina, Carmen (2007): Critical Performative Spaces: Identity, stance and discourse in process drama as critical literary interpretation. In: Blackburn, Molly \& Clark, Catherine (Eds.). New Directions in literacy research for teaching, learning and political action. New York, N.Y.: Peter Lang Publishers, 255-275

Wilder, Laura Ingalls (1992): Little House on the Prairie. New York, NY: HarperCollins 